\title{
Single Nucleotide Polymorphisms of GnRHR Gene and Its Relationship with Reproductive Performance in Egyptian Buffaloes
}

\author{
A.S.A. Sosa ${ }^{*}$, Karima Gh. M. Mahmoud*, H.A. Eldebaky ${ }^{*}$, \\ M.M.M. Kandiel ${ }^{* *}$, M.E.A. Abou El-Roos ${ }^{* *}$ and M.F. \\ Nawito \\ *Department of Animal Reproduction \& A. I., National Research \\ Centre, Cairo and ${ }^{* *}$ Department of Theriogenology, Faculty of \\ Veterinary Medicine, Benha University, Kaliobia, Egypt.
}

\begin{abstract}
7 TIS WORK aimed to search for single nucleotide polymorphisms of gonadotropin releasing hormone receptor (GnRHR) gene in Egyptian buffalo which involved in endocrine control of fertility. An ultrasonographic examinations of anestrum and repeat breeders' buffaloes were performed prior to blood sampling through a transrectal ultrasonography. DNA was extracted from blood and the PCR and singlestrand conformation polymorphism (SSCP) techniques were adopted to study of GnRHR gene polymorphism. The PCR amplified a fragment with 240-bp in size and the SSCP results showed that there is a genetic polymorphism with three different patterns (AA, BB and CC) in Egyptian buffalo. The CC genotype was associated with smooth inactive ovary, while BB genotype was associated with fertility in buffalo. Multiple sequence alignment of the three patterns sequences revealed that GnRHR had 5 single nucleotide polymorphisms including one nucleotide insertion, one nucleotide deletion and 3 nucleotide substitutions. Insertion was at position 4 in pattern III. The deletion was at position 189 in pattern III, while the 3 nucleotide substitutions were at positions 204 (T/G), 206 (T/A) and 207 (A/T). In conclusion, GnRHR gene could be used as a candidate marker for fertility in Egyptian buffaloes with its mutation is related to ovarian inactivity.
\end{abstract}

Keywords: Buffalo, GnRHR Gene, Nucleotide sequences, SSCP analysis.

Gonadotropin-releasing hormone is the key that plays important roles in vertebrate reproduction (Krieger et al., 1982). Its function is to stimulate the synthesis and release of pituitary gonadotropins (follicle stimulating hormone and luteinizing hormone) which regulate gametogenesis and steroidogenesis at gonadal level (Okuzawa and Kobayashi, 1999).

*Corresponding Author: Karima Gh. M. Mahmoud, Tel.: 002 01001827716, Fax: 0020233370931

E-mail: karimamahmoud@yahoo.com 
The interaction of GnRH with its receptor is important in the endocrine control of reproduction. The response of pituitary gonadotropes to GnRH correlates with the concentration of $\mathrm{GnRH}$ receptors on the cell surface (Wise et al., 1984). Mutations in GnRHR gene were found to be responsible for many reproductive genetic disorders in humans (Rosenthal et al., 1994) such as hypogonadotropic hypogonadism during puberty (Kottler et al., 1999).

The GnRHR gene is a good candidate gene for mutation analysis associated with reproductive performance. The polymorphism in promoter region of GnRHR had been associated with transmitting ability for days to first service in cattle (Derecka et al., 2010). Moreover, Yang et al. (2011) reported that A- or C alleles had favorable positive effects on sperm quality traits in bulls. In bovine, Liron et al. (2011) reported that European Bostaurus had lower frequencies of the $\mathrm{C}$ allele than $B$. indicus, while Creole and Wagyu breeds had intermediate frequency.

Molecular basis controlling physiological pathways related to infertility in buffalo still unknown. Therefore, the current study was aimed to detect the genetic polymorphism of GnRHR gene and its relation to fertility in Egyptian buffalo.

\section{Material and Methods}

Animals

A total numbers of 186 female Egyptian buffaloes belonged to Meet Kenana village, Qaluobia with the history of anestrum $(n=42)$, repeat breeding $(n=28)$ and fertile $(n=116)$ were used in this study during the year of 2013. Animals were admitted to the veterinary clinic with owner complains were infertility problems treatment or pregnancy diagnosis. Case history of each animal was recorded. Rectal and ultrasonographic examinations were accomplished once for three successive weeks to define the animal reproductive status and/or disorder.

\section{Blood sampling and DNA isolation}

Blood samples were taken before gynecological examination from jugular vein with vacutainer tubes containing EDTA as anticoagulant. Genomic DNA was extracted with the QIAamp DNA blood kit (QIAGEN GmbH, Hilden, Germany) according to the manufacturer's instructions.

\section{PCR Reaction and DNA Amplification}

Polymorphism was evaluated using primers designed for Egyptian buffalo GnRHR gene. The primers used in this study for amplification of 240-bp fragments of GnRHR gene were those described by Milazotto et al.(2008) with the following nucleotide sequence:

F: AAACTACAACTGAATCAGTC

R: TAGAGAGAAATATCCATATA

Egypt. J. Vet. Sci. Vol. 47, No.1 (2016) 
Amplification reactions were done in $50 \mu$ volume, containing $5.00 \mu \mathrm{l}$ buffer $10 \mathrm{x}, 1.00 \mu \mathrm{l}$ of $2.5 \mathrm{mM}$ (dNTPs mixture), $0.30 \mu \mathrm{l} \mathrm{Taq}$ polymerase $(5 \mathrm{U} / \mu \mathrm{l}), 0.25 \mu \mathrm{l}$ primer, $3.00 \mu \mathrm{l}$ of $25 \mathrm{mM}\left(\mathrm{MgCL}_{2}\right), 35.20 \mu \mathrm{l}$ water (nuclease free water) and 5.00 $\mu 1$ DNA sample. The PCR conditions were: one cycle at $95{ }^{\circ} \mathrm{C}$ for $4 \mathrm{~min}$, and 35 cycles of the sequence: $95{ }^{\circ} \mathrm{C}$ for $60 \mathrm{sec}$., $55^{\circ} \mathrm{C}$ for $30 \mathrm{sec}$. and $72{ }^{\circ} \mathrm{C}$ for $60 \mathrm{sec}$. Upon completion of the reaction, the products were subjected to electrophoresis in $2 \%$ agarose gel at $60 \mathrm{~V}$ for $2 \mathrm{hrs}$. Visualization of the bands was done under ultraviolet Trans-illumination and a photo was taken in Bio-Rad Gel-Doc. System. The amplified product size was compared with the 100bp Ladder DNA marker.

Single strand conformation polymorphism (SSCP)

The SSCP was used to screen the mutations in the amplified segment. PCR products $(7.00 \mu \mathrm{l})$ were mixed with $8.00 \mu$ lof denaturing solution $(98 \%$ formamide;20mM EDTA, pH 8.0; $0.05 \%$ bromophenol blue; $0.05 \%$ xylene cyanol). After that, the samples were denatured by heating at $95{ }^{\circ} \mathrm{C}$ for $8 \mathrm{~min}$., then they were put on ice for $8 \mathrm{~min}$. and loaded in 1x TBE buffer on to12\% polyacrylamide gel consists of [29:1 acrylamide: bisacrylamide, $10 \mathrm{ml}$ 1xTBE buffer (Trisbase, Boric acid, $\mathrm{Na}_{2}$ EDTA), $2.5 \mathrm{ml}$ glycerol, $17.5 \mathrm{ml}$ deionized water, $400 \mu \mathrm{l}$ APS solution(ammonium per sulfate) and $40 \mu \mathrm{l}$ of TEMED (N, N, $\mathrm{N}^{\prime}, \mathrm{N}^{\prime}$-Tetramethylethylenediamine].Electrophoresis was carried out at $4{ }^{\circ} \mathrm{C}$, $90 \mathrm{~V}$ for $18 \mathrm{~h}$.Silver staining technique was used to visualize the separated DNAfragments with high sensitivity on polyacrylamide gels according to Sanguinetti et al.(1994) with some modification (Benbouza et al., 2006).

\section{Sequence analysis}

For genetic sequencing, the PCR product was refined by QIAquick PCR purification kit (QIAGEN). The PCR products giving unique SSCP band patterns were analyzed by direct sequencing by Macrogen Incorporation (Seoul, South Korea). Sequence data were analyzed and alignment was carried out using NCBI/BLAST/blastn suite. Sequence data were further analyzed for detecting single nucleotide polymorphism using BioEdit software.

\section{Results and Discussion}

Normal reproductive function necessitates the precise temporal and quantitative regulation of hormone excretion at all levels of the hypothalamicpituitary-gonadal axis. Failure of the normal pattern of GnRH gene leads to clinical disorder of idiopathic hypogonadotropic hypogonadism and infertility. In the present study, PCR-SSCP technique was used to study the polymorphism of GnRHR gene in female Egyptian buffaloes. Primers used in this study was a flanked 240-bp fragment of Egyptian buffaloes GnRHR gene (Fig.1). The gene locus of GnRHR was found to be polymorphic with three different SSCP patterns in buffaloes (Fig.2). Pattern I (AA),II (BB) and III (CC) entailed four, 
five and six bands, respectively. Likewise, Kerekoppa et al.(2015) verified high genetic variation in GnRHR gene in cattle using PCR-SSCP technique, where fragment 1and 3 showed two patterns, fragment 2 and 4 exhibited three patterns and fragment 5 was monomorphic in bulls.

The DNA sequence of 207-bp fragment of buffaloes GnRHR gene out of the amplified 240-bp was determined and sequence alignment with published sequence of Egyptian buffaloes (Bubalus bubalis) gonadotropin-releasing hormone receptor, mRNA sequence (accession number:NM_001290857.1) was carried out using BLAST. The 207bp segment possessed99 \% identities (Fig.3).Current study results also revealed that the sequence of the same DNA segment was $99 \%$ identities with the accession number: GenBank: gbEU621854.1 (Fig.4). Multiple sequence alignment of the three patterns sequences (Fig.5) revealed that GnRHR gene had five SNPs (single nucleotide polymorphisms) including one nucleotide insertion, one nucleotide deletion and three nucleotides substitution. In pattern III, insertion was at position 4 , deletion was at position 189, and the 3 nucleotides substitutions were at positions 204 (T/G), 206 (T/A) and 207 (A/T). In this respect, Kerekoppa et al. (2015) reported high degree of genetic variation (14 SNPs) in the coding region of GnRHR gene among Holstein Friesian, Jersey, Malnad Gidda, and Deoni cattle. Also, Lirón et al. (2011) characterized bovine GNRHR polymorphisms in beef bulls and found eight SNPs of which five in the coding regions, might at least part responsible for the differences within and among beef breeds in the time when bulls reach puberty.Li et al. (2011) showed that the polymorphisms detected by PCR-SSCP and DNA sequencing methods of the GnRHR gene were significantly associated with litter size in Shaanan and Boer goats.

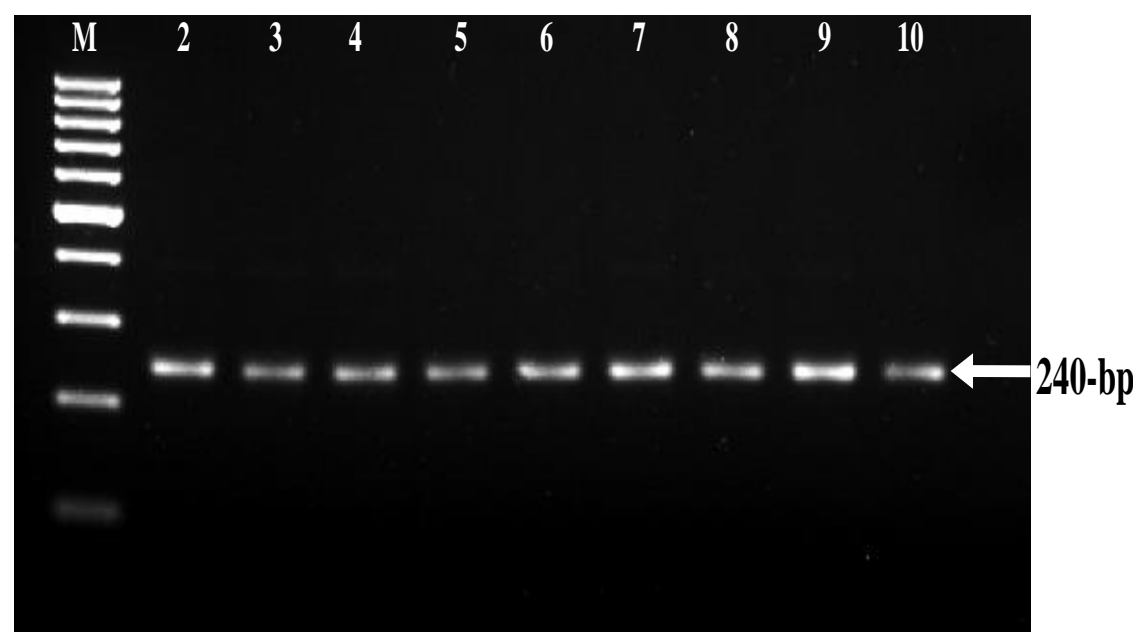

Fig. 1. Agarose gel stained with ethidium bromide showing the PCR product of buffalo GnRHR gene. M: 100-bp ladder. Lanes 2-10 :240-bp PCR product of GnRHR gene.

Egypt. J. Vet. Sci. Vol. 47, No.1 (2016) 
$\mathbf{a}$
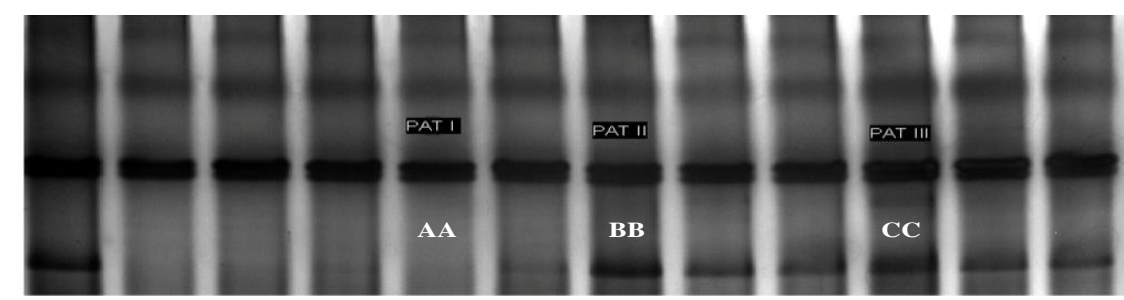

b
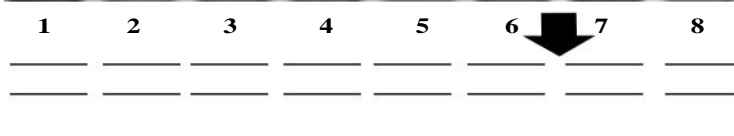

10

$11 \quad 12$

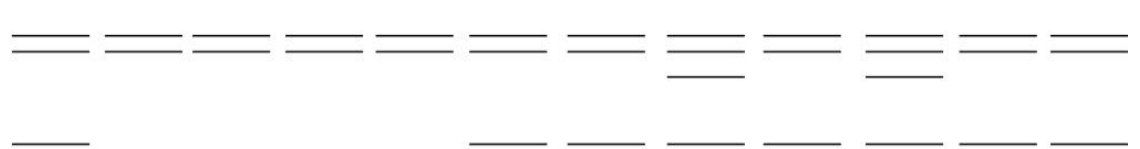

Fig. 2. a. Three different SSCP patterns of GnRHR gene in tested Egyptian buffalo on $12 \%$ silver stained-polyacrylamide gel. Lanes : 2-3-4-5: pattern I (AA). Lanes : 1- 6-7-911-12: pattern II (BB). Lanes : 8-10: pattern III (CC). b) Diagram showing SSCP banding patterns of $240 \mathrm{bp}$ fragment of GnRHR gene of Egyptian buffaloes.

Query 1 TCGGCTGAGGACCTT-AAGATGACGGTTGCATT'GCCACTICATTTACTGTCTGCTGGAC 59

Sbjct 790 TCGGCTGAGGACCTTAAAGATGACGGTTGCATTTGCCACTTCATTTACTGTCTGCTGGAC 849

Query 60 TCCCTACTATGTCCTTGGAMTTGGTATTGGTTTGATCCTGACATGGTAAACAGGGTGTC 119

|| |||||||||||||||||||||||||||||||||||||||||||||||||||||||||||||

Sbjct 850 TCCCTACTATGTCCTTGGAATTTGGTATTGGTITGATCCTGACATGGTAAACAGGGTGTC 909

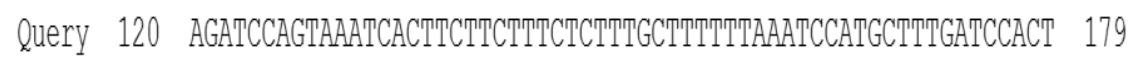
|||||||||||||||||||||||||||||||||||||||||||||||||||||||||||||||

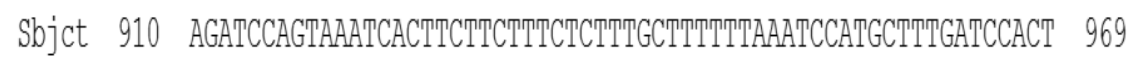

Query 180 TATATATGGATATTCTCTCTCTA-AATT 205

| |||||||||||||||||||||||| $\mid$

Sbjct 970 TATATATGGATATTTCTCTCTATAATT 996

Fig. 3. Sequence analysis of 207 segment of Egyptian buffalo gonadotropin-releasing hormone receptor (GnRHR) amplified product compared to Bubalus bubalis (GnRHR). GnRHR mRNA Sequence ID: NM_001290857.1.

Egypt. J. Vet. Sci. Vol. 47, No.1 (2016) 
Query 1 TCGGCTGAGGACCTT-AAGATGACGGTTGCATTTGCCACTTCATTTACTGTCTGCTGGAC 59

||||||||||||||| |||||||||||||||||||||||||||||||||||||||||||||

Sbjct 790 TCGGCTGAGGACCTTAAAGATGACGGTTGCATTTGCCACTTCATTTACTGTCTGCTGGAC 849

Query 60 TCCCTACTATGTCCTTGGAATTTGGTATTGGTTTGATCCTGACATGGTAAACAGGGTGTC 119

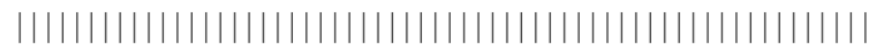

Sbjct 850 TCCCTACTATGTCCTTGGAATTGGTATTGGTTTGATCCTGACATGGTAAACAGGGTGTC 909

Query 120 AGATCCAGTAAATCACTTCTTCTTTCTCTTTGCTT"TT'AAATCCATGCTTTGATCCACT 179

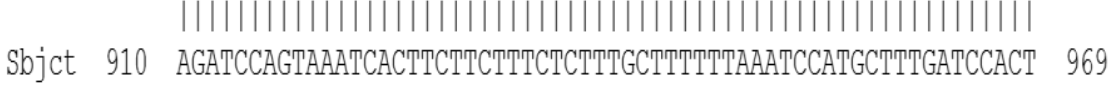

Query 180 TATATATGGATATTTCTCTCTA-AATT 205

Sbjct 970 TATATATGGATATTTCTCTCTATAATT 996

Fig. 4. Sequence analysis of 207 segment of Egyptian buffalo GnRHR amplified product compared with Bubalus bubalis pituitary type-I GnRH mRNA, complete cds Sequence ID: EU621854.1..

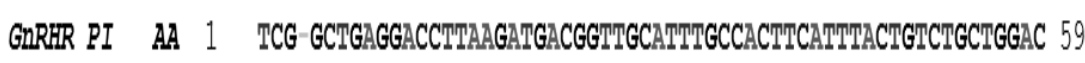

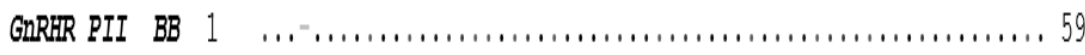

GRRRR PIII CC 1 ,

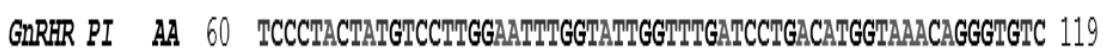

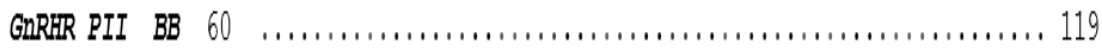

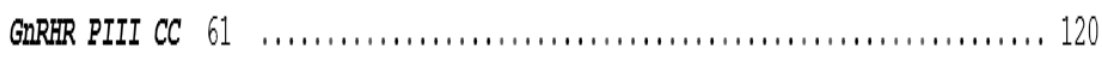

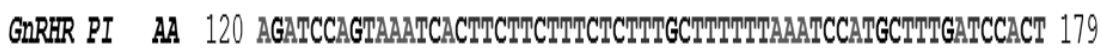

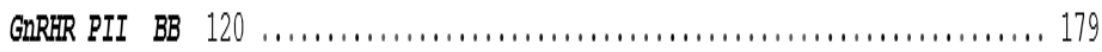

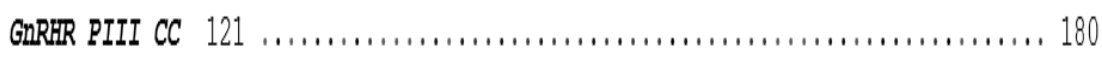

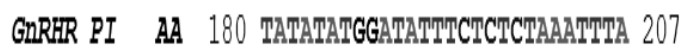

GRRIR PII BB $180 \ldots \ldots \ldots \ldots \ldots \ldots \ldots \ldots \ldots, 207$

GMRER PIII CC $181, \ldots \ldots \ldots, \ldots \ldots \ldots, \ldots, \mathbb{T} 207$

Fig. 5. Multiple sequence alignment of 3 different patterns of GnRHR gene of Egyptian buffaloes by BioEdit showed 5 SNPs.

Egypt. J. Vet. Sci. Vol. 47, No.1 (2016) 
In the current study, allele-frequency analysis of genetic polymorphism patterns of GnRHR gene locus in investigated buffaloes (Table 1) revealed that pattern I (AA) was the most encountered compared with patterns II (BB) and III (CC) $(51.7 \%$ vs. $44.1 \%$ and $4.3 \%$, respectively).Similarly, Liron et al. (2011) noticed lower frequencies of the $\mathrm{C}$ allele in European Bostaurus than B. indicus, meanwhile intermediate frequency of GnRHR alleles was recorded in Creole and Wagyu breeds.

TABLE 1. Patterns and frequencies of gonadotropin releasing hormone receptors gene polymorphism in fertile and infertile Egyptian buffaloes.

\begin{tabular}{|c|c|c|c|c|c|c|c|}
\hline \multicolumn{2}{|c|}{ Pattern } & \multirow{4}{*}{$\begin{array}{c}\begin{array}{c}\text { Fertile } \\
\text { animals }\end{array} \\
\\
56 \\
\end{array}$} & \multicolumn{4}{|c|}{ Infertile animals } & \multirow{4}{*}{$\begin{array}{c}\text { Total } \\
\\
96 \\
\end{array}$} \\
\hline & & & \multicolumn{2}{|c|}{ Anestrum } & \multirow{2}{*}{$\begin{array}{c}\begin{array}{c}\text { Repeat } \\
\text { breeder } \\
\text { (Abnormal } \\
\text { Uterus) }\end{array} \\
\end{array}$} & \multirow[t]{2}{*}{ Total } & \\
\hline & & & $\begin{array}{c}\text { Abnormal } \\
\text { ovary }\end{array}$ & $\begin{array}{c}\text { Abnormal } \\
\text { ovary and } \\
\text { uterus }\end{array}$ & & & \\
\hline \multirow{2}{*}{$\begin{array}{l}\text { Pattern I } \\
\text { (AA) }\end{array}$} & $\mathrm{n}$ & & 8 & 18 & 14 & 40 & \\
\hline & $\%$ & $58.33 \%$ & $8.33 \%$ & $18.75 \%$ & $14.58 \%$ & $\begin{array}{c}41.66 \\
\%\end{array}$ & $\begin{array}{c}51.62 \\
\%\end{array}$ \\
\hline \multirow{2}{*}{$\begin{array}{l}\text { Pattern II } \\
\text { (BB) }\end{array}$} & $\mathrm{n}$ & 60 & 6 & 2 & 14 & 22 & 82 \\
\hline & $\%$ & $73.17 \%$ & $7.31 \%$ & $2.43 \%$ & $17.07 \%$ & $\begin{array}{c}26.82 \\
\%\end{array}$ & $\begin{array}{c}44.08 \\
\%\end{array}$ \\
\hline \multirow{2}{*}{$\begin{array}{l}\text { Pattern } \\
\text { III } \\
\text { (CC) }\end{array}$} & $\mathrm{n}$ & 0 & 8 & 0 & 0 & 8 & 8 \\
\hline & $\%$ & 0 & $100 \%$ & 0 & 0 & $100 \%$ & $\begin{array}{c}4.30 \\
\% \\
\end{array}$ \\
\hline \multirow[b]{2}{*}{ Total } & $\mathrm{n}$ & 116 & 22 & 20 & 28 & 70 & 186 \\
\hline & $\%$ & $62.4 \%$ & - & - & - & $\begin{array}{c}37.6 \\
\%\end{array}$ & $100 \%$ \\
\hline
\end{tabular}

The ultrasound findings were used as the phenotype information to classify the animals into fertile and infertile animals. Accordingly, 116 animals were considered as fertile and represented about $62.4 \%$.On the other hand, 70 animals were found to suffer from infertility and those represent $37.6 \%$ of total tested animals. Pattern I (AA) was seen in 96 animals, with an incidence of 58.33\% and $41.66 \%$ in fertile and infertile animals, respectively. Pattern II (BB) appeared in 82 animals with a frequency of $73.2 \%$ and $26.8 \%$ in fertile and infertile buffaloes, respectively. Pattern III (CC) was displayed in 8 animals with an incidence of $100 \%$ in infertile animals suffered from smooth inactive ovary. These results suggested the precision of the predictability of the phenotype of animals fertility with approximately $58.33 \%, 73.2 \%$ and $100 \%$ accuracy for pattern I, II and III, respectively, with the latter was associated with low fertility phenotype. GnRHR mutations have been found to decrease GnRHR binding and/or activation of inositol triphosphate or phospholipase $\mathrm{C}$ and are related to idiopathic hypogonadotropic hypogonadism or Kallmann's syndrome in humans (Tamaya, 2002). It is possible that the mutations in GnRHR gene influence sex 
hormone levels which significantly impact on reproduction (Sun et al., 2008). In addition, naturally occurring mutations in GnRHR was demonstrated to be responsible for human genetic disorders (Kottler et al., 2000). Moreover, Sedlmeyer et al. (2005)found three SNPs associated with late pubertal development, another SNP associated with late menarche, and one rare haplotype associated with early age of menarche.

\section{Conclusion}

GnRHR gene in the Egyptian buffaloes is polymorphic with three different SSCP patterns (AA, BB and CC). The CC genotype was associated with ovarian disorders and $\mathrm{BB}$ genotype was associated with fertility in buffalo. These results suggest that GnRHR gene could be implied as a candidate marker for fertility in Egyptian buffaloes.

Acknowledgments : This research was supported by National Research Centre, Cairo, Egypt. Project number 10060116.

\section{References}

Benbouza, H., Jacquemin, J.M., Baudoin, J.P. and Mergeai, G. (2006) Optimization of a reliable, fast, cheap and sensitive silver staining method to detect SSR markers in polyacrylamide gels. Biotechnol. Agron. Soc. Environ., 10, 77-81.

Derecka, K., Ahmad, S., Hodgman, T.C., Hastings, N., Royal, M.D., Woolliams, J.A. and Flint, A.P.F. (2010) Sequence variants in the bovine gonadotrophin releasing hormone receptor gene and their associations with fertility. Anim. Genet., 41, 329-331.

Kerekoppa, R., Basavaraju, M., Rao, A., Geetha, G. R. , Mukund, K. and Sakthivel, J. (2015) Single nucleotide polymorphism identification and characterization of GnRHR gene in Bostaurus and Bosindicus cattle. Turk. J. Vet. Anim. Sci., 39, 10-15.

Kottler, M., Counis, R. and Bouchard, P. (1999) Mutations of the GnRH receptor gene, a new cause of autosomal-recessive hypogonadotropic hypogonadism. Arch. Med. Res., 30, 481-485.

Kottler, M.L., Chauvin, S., Lahlou, N., Harris, C.E., Johnston, C.J., Lagarde, J.P., Bouchard, P., Farid, N.R. and Counis, R. (2000)A new compound heterozygous mutation of the gonadotropin-releasing hormone receptor (L 314X, Q106R) in a woman with complete hypogonadotropic hypogonadism: chronic estrogen administration amplifies the gonadotropin defect. J. Clin. Endocrinol. Metab., 85, 3002-3008.

Krieger, D.T., Perlow, M.J., Gibson, M.J. Davies, T.F., Zimmerman, E.A., Ferin, M. and Charlton, H.M. (1982) Brain grafts reverse hypogonadism of gonadotropin releasing hormone deficiency. Nature, 298, $468-471$.

Li, G., Wu, H., Fu, M. and Zhou, Z. (2011) Novel single nucleotide polymorphisms of GnRHR gene and their association with litter size in goats. ArchivTierzucht, 54, 618-624.

Egypt. J. Vet. Sci. Vol. 47, No.1 (2016) 
Liron, J.P., Prando, A., Ripoli, M.V., Rogberg-Munoz, A., Posik, D.M., Baldo, A., Peral-Garcia, p. and Giovambattista, G. (2011) Characterization and validation of bovine gonadotripin releasing hormone receptor (GnRHR) polymorphisms. Research in Veterinary Science, 91, 391-396.

Milazzotto, M. P., Rahal, P., Nichi, M., Miranda-Neto, T., Teixeira, L.A., Ferraz, J.B.S.,Eler, J.P., Campagnari, F. and Garcia, J.F. (2008) New molecular variants of hypothalamus - pituitary - gonad axis genes and their association with early puberty phenotype in Bos Taurus indicus (Nellore). Live Stock Science, 114, 274-279.

Okuzawa, K. and Kobayashi, M. (1999) Gonadotropin-Releasing Hormone Neuronal Systems in the Teleostean Brain and Functional Significance. Kluwer Academic/Plenum, New York., pp. 85-100.

Rosenthal, I.M., Refetoff, S., Rich, B., Barnes, R.B. and Thongkum, S. (1996) Response to challenge with gonadotropin releasing hormone agonist a mother and her two sons with a constitutively activating mutation of the luteinizing hormone receptor. J Clin Endo., 81, 3802-3806.

Sanguinetti, C.J., Dias Neto, E. and Simpson, A.J.G. (1994) Rapid silver staining and recovery of PCR products separated on polyacrylamide gels. Biotechniques, 17, 915-919.

Sedlmeyer, I. L., LeighPearce, C.L., Trueman, J.A., Butler, J.L., Bersaglieri, T., Read,A.P., Clayton, P.E., Kolonel, L.N., Henderson, B.E., Hirschhorn, J.N. and Palmert, M.R. (2005) Structure for the gonadotropin-releasing hormone (GNRH) and GNRH receptor genes, investigation of role in pubertal timing. J. Clin. Endocrinol. Metab., 90, 1091-1099.

Sun, J., Chu, M. X. and Chen, H. Q. (2008) Polymorphism of GnRHR gene and its relationship with prolificacy of small tail Han sheep. J. AgriBiot., 16, 230-236.

Tamaya, T. (2002) Normosmic idiopathic hypogonadotropic hypogonadism with GnRH receptor mutation (review). Japanese J. Clin. Med., 60, 319-324.

Wise, M.E., Nieman, D., Stewart, J. and Nett, T.M. (1984) Effect of number of receptors for gonadotropin-releasing hormone on the release of luteinizing hormone. Biol. Reprod., 31, 1007-1013.

Yang, W.C., Tang, K. Q., Yu, J. N., Zhang, C.Y., Zhang, X. X. and Yang, L. G. (2011)Effects of MboII and BspMI polymorphisms in the gonadotropin releasing hormone receptor (GnRHR) gene on sperm quality in Holstein bulls. MolBiol. Rep., 38, 3411-3415.

(Received 29/ 9/2016; accepted 29/11/2016) 


\section{تعدد الطرز الوراثية للنيوكليتدات الأحادية لجين مستقبلات الهرمون

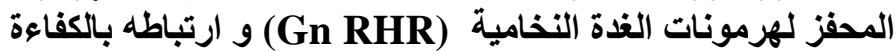

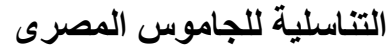

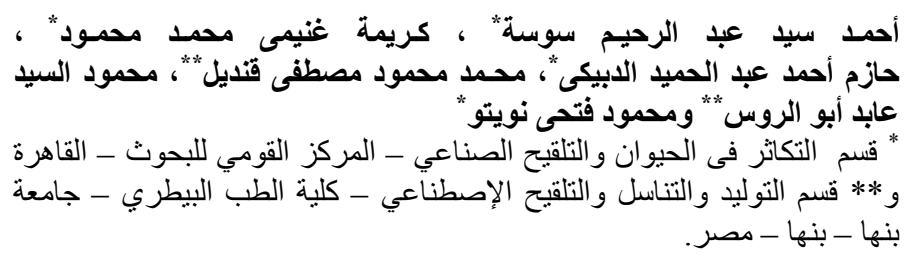

يهدف البحث إلى دراسة الطرز الجينية النتعددة فى النيوكلوتيدات الأحادية فى جين

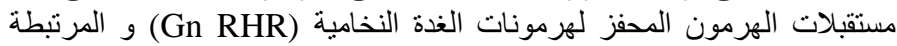

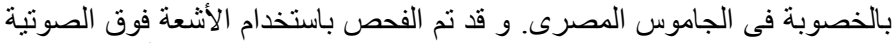

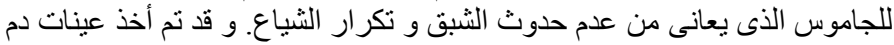

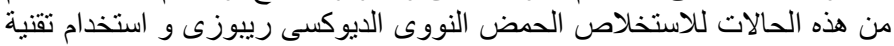

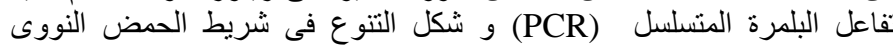

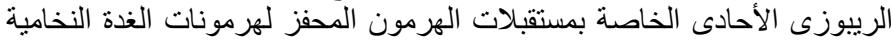

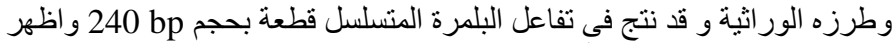

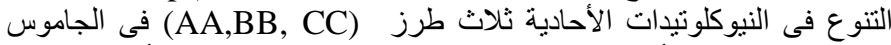

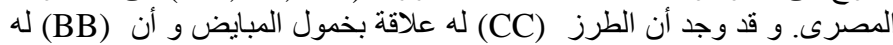

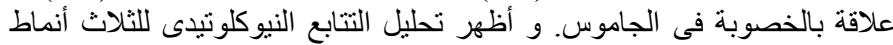

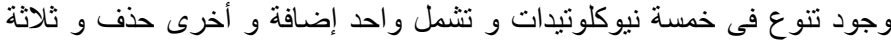

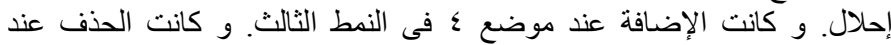

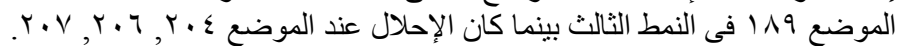

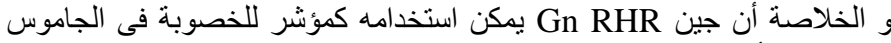
المصرى و أن طفر اته لها علاقة بخمول المبايض. 